Published in final edited form as:

Clin Chest Med. 2019 June ; 40(2): 439-448. doi:10.1016/j.ccm.2019.02.010.

\title{
Pulmonary Limitations in Heart Failure
}

\author{
Ivan Cundrle Jr., M.D., Ph.D., \\ Department of Anesthesiology and Intensive Care, St. Anne's University Hospital, Brno, Czech \\ Republic
}

Faculty of Medicine, Masaryk University, Brno, Czech Republic

International Clinical Research Center, St. Anne's University Hospital, Brno, Czech Republic, Ivan.Cundrle@seznam.cz

Lyle J. Olson, M.D., and

Department of Cardiovascular Diseases, Mayo Clinic, Rochester, MN, USA, olson.lyle@mayo.edu

Bruce D. Johnson, Ph.D.

Department of Cardiovascular Diseases, Mayo Clinic, Rochester, MN, USA, johnson.bruce@mayo.edu

\section{Summary}

Ultimately in the pathogenesis of heart failure, the disease becomes a systemic illness with a marked impact on the respiratory system. This creates a significant codependence between organ systems that is accentuated as the disease progresses and is further enhanced during exercise where the respiratory system becomes a major contributor to exertional symptoms and an important marker to track disease severity and prognosis.

\section{Keywords}

heart failure; cardiopulmonary exercise testing; ventilatory efficiency

\section{Introduction}

The heart and lungs are intimately related anatomically and physiologically as they share the enclosed thoracic cavity, are exposed to similar intrathoracic pressures, have a common surface area and are hemodynamically linked as the lungs accept nearly the entire cardiac output $^{1}$. Hence, changes in cardiac function may directly influence lung function due to alterations in cardiac preload and afterload including venous return and cardiac transmural pressure. Heart failure directly impacts 1) lung mechanics due to congestion and increased heart size which promote airway obstruction and lung restriction ${ }^{1,2}, 2$ ) high pulmonary

\footnotetext{
Correspondence to: Bruce D. Johnson.
}

Publisher's Disclaimer: This is a PDF file of an unedited manuscript that has been accepted for publication. As a service to our customers we are providing this early version of the manuscript. The manuscript will undergo copyediting, typesetting, and review of the resulting proof before it is published in its final citable form. Please note that during the production process errors may be discovered which could affect the content, and all legal disclaimers that apply to the journal pertain. 
pressures as well as pulmonary congestion contributes to remodeling of the pulmonary capillaries, increased ventilation-perfusion mismatch and decreased alveolar-capillary diffusion $^{3,4}$ and 3) disordered ventilatory control including hyperventilation at rest, during exercise and with sleep ${ }^{5-7}$. These pulmonary system changes cause decreased breathing reserve combined with enhanced ventilation for a given metabolic demand (minute ventilation $(\dot{\mathrm{V}} \mathrm{E}) /$ pulmonary carbon dioxide output $\left(\dot{\mathrm{V}} \mathrm{CO}_{2}\right)$ ratio) at rest and during exercise $^{7,8}$. In this review, we discuss heart failure (HF) related changes in lung mechanics, gas exchange and ventilatory control as well as their impact on the limitation of exercise capacity, sleep disordered breathing and prognosis of HF patients.

\section{Lung Volume and Flow in HF}

Pulmonary function is abnormal in HF patients including decreased bronchial conductance and restrictive lung volumes. Moreover, the observed flow limitation and lung restriction may increase the work of breathing which in combination with weak respiratory muscles may increase the sensation of dyspnea in HF patients ${ }^{8}$. Bronchial flow limitation has been attributed to airway compression (by pulmonary edema) and/or mucosal edema due to bronchial congestion (Figure 1) $)^{1,8-10}$ which may develop from either an increase in blood flow or an increase in blood volume without a change of flow due to increased cardiac filling pressure or pulmonary artery hypertension ${ }^{1}$. Several factors may influence bronchial blood flow in HF patients including increased left atrial pressure causing greater pulmonary vascular pressure and bronchial vessel stasis ${ }^{11}$; stretching of the left heart chambers which may lead to increased bronchial conductance ${ }^{12}$; rise in inflammatory and vasoactive mediators which may influence vasomotor tone and lead to vasodilatation and congestion of bronchial vessels ${ }^{13,14}$; and chronic hypocapnia which is a common manifestation of elevated left ventricular filling pressures in HF patients ${ }^{15}$ which may also lead to vasodilatation ${ }^{16}$.

Experimental studies have shown fluid overload leads to decrease of the diameter of both small ${ }^{17}$ and large airways ${ }^{18}$. Furthermore, pulmonary function test parameters have been shown to improve with diuresis in HF patients ${ }^{19}$. Agostoni et al. observed significantly higher bronchial shunt blood flow in patients with chronic HF than in non-HF patients during surgery on cardiopulmonary bypass suggesting the presence of either dilated or more numerous intrapulmonary bronchial blood vessels in patients with chronic $\mathrm{HF}^{11}$. Pulmonary artery hypertension (PAH), a frequent comorbidity in either HF with reduced (HFrEF) or preserved ejection fraction $(\mathrm{HFpEF})^{20}$ has been shown to contribute to bronchial airway obstruction by Meyer, et al., ${ }^{21}$ and others ${ }^{22-24}$.

Physiologic factors which may counteract hydrostatic forces which promote edema formation in the airways include sympathetic nervous system activation with a-adrenergic receptor mediated vasoconstriction in peri-bronchiolar vessels which may reduce congestion ${ }^{1}$. Furthermore, functional capillary remodeling with fibrosis and thickening of the alveolar-capillary membranes due to chronically increased pulmonary capillary pressure may occur ${ }^{25}$ causing increased resistance to high vascular pressures and interstitial edema development. Lymphatic drainage also progressively increases with the severity of $\mathrm{HF}^{26}$ which may serve as another adaptive mechanism to reduce pulmonary congestion. 
Olson, et al. have demonstrated a significant relationship between HF severity, heart size, intrathoracic volume and lung restriction ${ }^{2}$. Cardiac enlargement in HF has been shown by Agostoni et al., to promote restrictive lung function ${ }^{27}$. A close relation between pulmonary function and decrease in cardiac volume with heart transplantation was demonstrated by McCormack et al. ${ }^{28}$

\section{Gas Exchange Change in HF}

Gas exchange is often abnormal in patients with HF and correlates with disease severity ${ }^{29}$. Several studies have shown decreased lung diffusion factor for carbon monoxide $\left(\mathrm{D}_{\mathrm{L}} \mathrm{CO}\right)$ in patients with $\mathrm{HF}^{3,4}$. The cause is probably multifactorial and involves interstitial edema as well as alveolar-capillary membrane remodeling ${ }^{3,4}$. Furthermore, bronchial obstruction caused by peri-bronchial edema may reduce ventilation to some pulmonary units, increasing the ventilation-perfusion mismatch and further impairing gas exchange.

Pulmonary edema increases the distance between alveolar gas and red blood cells and may therefore also impair $\mathrm{D}_{\mathrm{L}} \mathrm{CO}$. However, in healthy subjects, infusion of normal saline has been associated with worsening of lung mechanics, though not $\mathrm{D}_{\mathrm{L}} \mathrm{CO}^{30}$, suggesting alveolar-capillary remodeling may have a higher impact on the $\mathrm{D}_{\mathrm{L}} \mathrm{CO}$ changes observed in HF patients. Alveolar-capillary remodeling involves fibrosis, thickening of the alveolarcapillary membranes ${ }^{25}$ and $\beta$-adrenergic receptor insufficiency of the alveolar epithelium ${ }^{31}$ which may result in inability to effectively clear alveolar fluid.

Impaired $\mathrm{D}_{\mathrm{L}} \mathrm{CO}$ has been associated with poor prognosis ${ }^{32}$ as well as low exercise performance ${ }^{33}$. Unfortunately, adverse remodeling of the alveolar-capillary membrane may not be fully reversible with $\mathrm{HF}$ treatment ${ }^{34}$. Only partial improvement of $\mathrm{D}_{\mathrm{L}} \mathrm{CO}$ with heart transplantation was shown by Mettauer et. al ${ }^{35}$ and no change to $\mathrm{D}_{\mathrm{L}} \mathrm{CO}$ with cardiac resynchronization therapy was shown by our group ${ }^{36}$.

Surfactant protein B appears to be a promising marker of alveolar-capillary membrane damage as it is not increased in edema with no alveolar damage ${ }^{37}$ and has been shown to correlate with HF severity ${ }^{38}$. Moreover, surfactant protein $\mathrm{B}$ has been shown to be associated with $\mathrm{HF}$ re-hospitalization ${ }^{39}$ and to be related to $\mathrm{D}_{\mathrm{L}} \mathrm{CO}^{40}$, peak oxygen consumption $\left(\mathrm{VO}_{2}\right)$ and $\mathrm{V}_{\mathrm{E}} / \mathrm{VCO}_{2}$ slope $^{38}$. Indeed, surfactant protein $\mathrm{B}$ may be a stronger prognostic marker than $\mathrm{D}_{\mathrm{L}} \mathrm{CO}^{41}$ and unlike $\mathrm{D}_{\mathrm{L}} \mathrm{CO}$ may decrease with $\mathrm{HF}$ clinical improvement ${ }^{39}$.

\section{Ventilatory Control in HF}

Ventilatory control is frequently abnormal in patients with advanced HF and manifests as hyperventilation at rest ${ }^{5}$, during exercise ${ }^{6}$ and with sleep ${ }^{7}$. The presence of hyperventilation has been associated with decreased functional capacity ${ }^{6}$, more severe symptoms ${ }^{42}$ and increased mortality ${ }^{43}$ in HF patients.

The etiology of hyperventilation in HF patients has not been fully elucidated, and may include activation of pulmonary C-fiber receptors due to congestion, activation of atrial stretch receptors, ventilation-perfusion mismatch and low systemic oxygen transfer capacity as well as increased activation of central and peripheral chemoreflexes and the 
ergoreflex ${ }^{6,42,44-49}$. Lactate acidosis was formerly believed to be a major cause of hyperventilation in HF patients ${ }^{50,51}$ though this concept has since been refuted ${ }^{52}$.

Cardiopulmonary exercise testing (CPET) allows evaluation of the ventilatory response to exercise which is abnormal in HF patients despite normal breathing reserve ${ }^{8}$. Normal ventilatory response includes an increase of minute ventilation $\left(\mathrm{V}_{\mathrm{E}}\right)$ caused by both increase in tidal volume $\left(\mathrm{V}_{\mathrm{T}}\right)$ at the beginning of exercise followed by an increase of breathing frequency $\left(f_{b}\right)$ towards peak exercise ${ }^{13}$. In HF, $V_{E}$ is significantly increased because of the increase in $\mathrm{f}_{\mathrm{b}}$ with little or no increase in $\mathrm{V}_{\mathrm{T}}{ }^{53}$. Ventilatory parameters routinely measured during CPET also include ventilatory efficiency $\left(\mathrm{V}_{\mathrm{E}} / \mathrm{VCO}_{2}\right)$ and partial pressure of end-tidal carbon dioxide $\left(\mathrm{P}_{\mathrm{ET}} \mathrm{CO}_{2}\right)$.

The $\mathrm{V}_{\mathrm{E}} / \mathrm{VCO}_{2}$ slope identifies and quantifies the magnitude of hyperventilation and has been found to be elevated ${ }^{54,55}$ and inversely correlated with cardiac output in HF patients ${ }^{55}$. Importantly, many studies in HF patients have shown $\mathrm{V}_{\mathrm{E}} / \mathrm{VCO}_{2}$ to be a better predictor of clinical outcome than peak $\mathrm{VO}_{2}{ }^{56-60}$. Ventilatory efficiency is inversely related to the partial pressure of arterial $\mathrm{CO}_{2}\left(\mathrm{PaCO}_{2}\right)$ and positively to the dead space / tidal volume ratio $\left(\mathrm{V}_{\mathrm{D}} / \mathrm{V}_{\mathrm{T}}\right)$ by the alveolar gas equation $\mathrm{V}_{\mathrm{E}} / \mathrm{VCO}_{2}=863 /\left(\mathrm{PaCO}_{2} \times\left(1-\mathrm{V}_{\mathrm{D}} / \mathrm{V}_{\mathrm{T}}\right)\right)$. From this relationship, it is clear the $\mathrm{V}_{\mathrm{E}} / \mathrm{VCO}_{2}$ may be increased by lowering of the $\mathrm{PaCO}_{2}$ or increasing the $\mathrm{V}_{\mathrm{D}} / \mathrm{V}_{\mathrm{T}}$ ratio. Increased stimulation or increased sensitivity of pulmonary receptors, increased sympathetic nerve activity, peripheral and central chemoreceptors and ergoreceptors may cause hyperventilation and reduction of $\mathrm{PaCO}_{2}$. Conversely, the $\mathrm{V}_{\mathrm{D}} / \mathrm{V}_{\mathrm{T}}$ ratio may be effected by ventilation-perfusion mismatch including a rapid and shallow breathing pattern ${ }^{6}$. Woods et al., quantified the contribution of $\mathrm{PaCO}_{2}$ and $\mathrm{V}_{\mathrm{D}} / \mathrm{V}_{\mathrm{T}}$ to the increased $\mathrm{V}_{\mathrm{E}} / \mathrm{VCO}_{2}$ in $\mathrm{HF}$ patients and found nearly similar contribution of $\mathrm{PaCO}_{2}$ and $\mathrm{V}_{\mathrm{D}} / \mathrm{V}_{\mathrm{T}}{ }^{6}$ (Figure 2).

Low $\mathrm{P}_{\mathrm{ET}} \mathrm{CO}_{2}$ during exercise has also been shown to reflect functional, ventilatory and cardiac performance in HF patients by Myers et al. ${ }^{61}$. Furthermore, rest $\mathrm{P}_{\mathrm{ET}} \mathrm{CO}_{2}$ has also been shown to be useful in $\mathrm{HF}$ prognostication ${ }^{62}$, and to add incremental prognostic value to $\mathrm{V}_{\mathrm{E}} / \mathrm{VCO}_{2}$ slope ${ }^{5}$. Rest $\mathrm{P}_{\mathrm{ET}} \mathrm{CO}_{2}$ has also been demonstrated to be an independent predictor of left ventricular assist device implantation ${ }^{63}$. $\mathrm{P}_{\mathrm{ET}} \mathrm{CO}_{2}$ has been integrated into two CPET scoring systems for adverse event prediction in $\mathrm{HF}^{64,65}$. $\mathrm{P}_{\mathrm{ET}} \mathrm{CO}_{2}$ may be decreased by hyperventilation and by increased dead space ventilation, i.e., by the same factors which determine $\mathrm{V}_{\mathrm{E}} / \mathrm{VCO}_{2}{ }^{6}$, suggesting the parameters are closely related ${ }^{61}$. In our previous studies we have shown HF patients with low $\mathrm{P}_{\mathrm{ET}} \mathrm{CO}_{2}$ and increased $\mathrm{V}_{\mathrm{E}} / \mathrm{VCO}_{2}$ at peak exercise also exhibit low $\mathrm{P}_{\mathrm{ET}} \mathrm{CO}_{2}$ and increased $\mathrm{V}_{\mathrm{E}} / \mathrm{VCO}_{2}$ at rest ${ }^{7,66}$ suggesting factors which promote high $\mathrm{V}_{\mathrm{E}} / \mathrm{VCO}_{2}$ and low $\mathrm{P}_{\mathrm{ET}} \mathrm{CO}_{2}$ may not be limited to exercise.

\section{Periodic Breathing, Exercise Oscillatory Ventilation and Central Sleep Apnea}

Periodic breathing $(\mathrm{PB})$ is a consequence of respiratory control system instability characterized by waxing and waning of tidal volume with or without interposed apnea ${ }^{49}$ due to oscillations of central respiratory drive ${ }^{67}$. $\mathrm{PB}$ may appear either at rest ${ }^{68}$, during exercise $^{69}$ or with sleep ${ }^{70}$. It has been shown that PB occurs mostly in the situations where 
ventilation is mainly under metabolic control. During sleep it occurs with non-rapid eye movement sleep ${ }^{70}$ and during exercise it is the time when the increased metabolic demand for $\mathrm{O}_{2}$ consumption and $\mathrm{CO}_{2}$ production cause respiratory control to fall mainly under the influence of the metabolic respiratory control system ${ }^{71}$.

Oxygen delivery and $\mathrm{CO}_{2}$ excretion are physiologically maintained by the respiratory and circulatory systems. Stability of these systems is maintained by several feedback loops involving a central controller comprised of peripheral and central chemoreceptors stimulating the brainstem respiratory motor neurons and a peripheral working unit comprised of lungs, rib cage and respiratory muscles ${ }^{67}$. Several factors may destabilize the respiratory control system and produce the PB pattern observed in HF patients. Prolonged circulatory time may cause delay in the information transfer between lungs and chemoreceptors ${ }^{72}$; increased $\mathrm{CO}_{2}$ chemosensitivity with increased chemoreceptor gain may lead to over-correction of $\mathrm{PaCO}_{2}$ deviations from the arterial $\mathrm{CO}_{2}$ setpoint ${ }^{69}$; and the $\mathrm{CO}_{2}$ setpoint may be lowered closer to the apnea threshold by hyperventilation caused by either activation of pulmonary C-fibers due to congestion, activation of left atrial stretch receptors by volume overload, ventilation-perfusion mismatch, increased sympathetic nerve activity or modulation of the ergoreflex ${ }^{6,44-49,73}$. Taken together, PB is a manifestation of control system failure, caused by signal underdamping with periodic over and undershooting of ventilation ${ }^{67}$. During sleep, the development of apnea depends mainly on the frequency of oscillations; the lower the frequency, the higher the amplitude and the higher the chance of crossing the $\mathrm{CO}_{2}$ apnea threshold ${ }^{70}$. Indeed, inhalation of $3 \% \mathrm{CO}_{2}$ eliminates Cheyne Stokes respiration of patients with $\mathrm{HFrEF}^{74}$.

In contrast, no association between $\mathrm{PaCO}_{2}$ at rest and during exercise and $\mathrm{EOV}$ (presence, duration, amplitude) was found in the study of Murphy et $\mathrm{a}^{75}$. And in the same study, EOV was shown to be associated with increased cardiac filling pressure ${ }^{75}$ supporting the concept of activation of pulmonary $\mathrm{C}$-fibers and hyperventilation. However, this observation has been questioned by others who found EOV to disappear during late exercise despite an increase in pulmonary capillary wedge pressure ${ }^{76}$. These observations suggest that EOV pathophysiology is complex and likely involves multiple factors.

The American Heart Association has defined EOV as an oscillatory ventilatory pattern that persists for at least $60 \%$ of exercise at an amplitude of $15 \%$ or more of the average resting value $^{77,78}$ (Figure 3). By CPET, EOV has been detected in 19-51\% of HFrEF patients ${ }^{75}$ and similar prevalence has been observed in HFpEF patients ${ }^{79}$. EOV has been associated with increased risk of death ${ }^{73,80}$. Moreover, the risk of death is further increased in HF patients with EOV and increased $\mathrm{V}_{\mathrm{E}} / \mathrm{VCO}_{2}$ slope ${ }^{81}$. Guazzi et al. found EOV to be the strongest predictor of cardiac events in $\mathrm{HFpEF}$ patients ${ }^{79}$ and in patients without clinical manifestations of $\mathrm{HF}^{82}$. The risk of death is further increased if EOV is combined with abnormal breathing during sleep ${ }^{83}$. The prevalence of EOV is similar to the prevalence of $\mathrm{CSA}$ and the presence of EOV is highly predictive of the presence of $\mathrm{CSA}^{84}$ suggesting shared pathophysiology.

In HF patients, CSA is characterized as a crescendo-decrescendo breathing pattern with hyperventilation alternating with compensatory apnea ${ }^{85,86}$. CSA is considered a 
consequence of $\mathrm{HF}^{86-90}$, is linked to the hemodynamic severity of $\mathrm{HF}^{91,92}$ and associated with increased hospital readmission rates ${ }^{93}$ and mortality ${ }^{94}$. In a previous study by our group, we have shown $\mathrm{HF}$ patients with CSA exhibit higher central $\mathrm{CO}_{2}$ chemosensitivity, increased $\mathrm{V}_{\mathrm{E}}$ and lower $\mathrm{P}_{\mathrm{ET}} \mathrm{CO}_{2}$ at rest, higher $\mathrm{V}_{\mathrm{E}}, \mathrm{V}_{\mathrm{T}}$ and $\mathrm{V}_{\mathrm{E}} / \mathrm{VCO}_{2}$ ratio and lower $\mathrm{P}_{\mathrm{ET}} \mathrm{CO}_{2}$ during exercise, and higher $\mathrm{V}_{\mathrm{E}} / \mathrm{VCO}_{2}$ ratio and lower $\mathrm{P}_{\mathrm{ET}} \mathrm{CO}_{2}$ at peak exercise ${ }^{7}$. Moreover, we have shown central $\mathrm{CO}_{2}$ chemosensitivity, peak $\mathrm{P}_{\mathrm{ET}} \mathrm{CO}_{2}$ and peak $\mathrm{V}_{\mathrm{E}} / \mathrm{VCO}_{2}$ ratio to be independently associated with the presence of CSA and to correlate with CSA severity ${ }^{7}$. These observations suggest the presence of abnormal ventilatory control of HF patients with hyperventilation at rest, during exercise and with sleep and may promote recognition of the CSA phenotype during $\mathrm{CPET}^{7}$.

\section{Special Considerations for HFpEF}

$\mathrm{HFpEF}$ is frequent and accounts for more than half of HF cases ${ }^{95}$. Moreover, HFpEF is associated with increased risk of hospitalization and death ${ }^{96,97}$. Guazzi et al showed $\mathrm{V}_{\mathrm{E}} / \mathrm{VCO}_{2}$ but not peak $\mathrm{VO}_{2}$ to be associated with all cause and cardiac related mortality and hospitalization in patients with $\mathrm{HFpEF}^{79,98}$. These result were supported by Yan et al., who also showed $\mathrm{V}_{\mathrm{E}} / \mathrm{VCO}_{2}$ but not peak $\mathrm{VO}_{2}$ to be associated with all-cause mortality in patients with $\mathrm{HFpEF}^{99}$. In contrast, Shafiq et al. showed an association of peak $\mathrm{VO}_{2}$ but not $\mathrm{V}_{\mathrm{E}} /$ $\mathrm{VCO}_{2}$ with all-cause mortality and cardiac transplant ${ }^{100}$. Finally, Nadruz et al showed both $\mathrm{V}_{\mathrm{E}} / \mathrm{VCO}_{2}$ and peak $\mathrm{VO}_{2}$ to be independent prognostic tools in $\mathrm{HFpEF}^{101}$.

\section{Special Considerations for Pulmonary Artery Hypertension}

Chronically increased cardiac filling pressure is a common cause of PAH in both patients with $\mathrm{HFrEF}$ and $\mathrm{HFpEF}^{20}$. The prevalence of this comorbidity is high in patients with HFrEF (up to $72 \%$ ) ${ }^{102}$ and in patients with HFpEF (up to $83 \%$ ) ${ }^{103}$. PAH is associated with exercise dyspnea, increased $\mathrm{V}_{\mathrm{E}} / \mathrm{VCO}_{2}$ slope and poor prognosis ${ }^{104}$. Physiologically, $\mathrm{V}_{\mathrm{E}} / \mathrm{VCO}_{2}$ decreases and $\mathrm{P}_{\mathrm{ET}} \mathrm{CO}_{2}$ increases from rest to peak exercise ${ }^{105}$. This physiological pattern may also be observed in patients with $\mathrm{HF}^{7,106}$. In contrast, in patients with moderate to severe $\mathrm{PAH}, \mathrm{V}_{\mathrm{E}} / \mathrm{VCO}_{2}$ was found to increase ${ }^{107}$ and $\mathrm{P}_{\mathrm{ET}} \mathrm{CO}_{2}$ to decrease during exercise because of poor pulmonary perfusion ${ }^{108}$. In patients with $\mathrm{PAH}$, ventilatory response to exercise seems to be more closely related to ventilatory-perfusion mismatch and increased ventilatory drive than altered pulmonary mechanics ${ }^{109}$.

\section{Acknowledgements:}

Dr. Cundrle is supported by Czech Republic Ministry of Health [grant NV18-06-00216]; National Program of Sustainability II (MEYS CR) [project no. LQ1605] and by the project FNUSA-ICRC [CZ.1.05/1.1.00/02.0123 (OP $\mathrm{VaVpI})]$. The majority of work funding Dr. Johnson's laboratory relative to this review was from NIH Grant HL71478.

\section{Abbreviations}

CPET

CSA

$\mathrm{D}_{\mathrm{L}} \mathrm{CO}$ cardiopulmonary exercise testing

central sleep apnea

lung diffusion factor for carbon monoxide 


\begin{tabular}{|c|c|}
\hline EOV & exercise oscillatory ventilatory \\
\hline $\mathbf{f}_{\mathbf{b}}$ & breathing frequency \\
\hline HFpEF & heart failure with preserved ejection fraction \\
\hline HFrEF & heart failure with reduced ejection fraction \\
\hline $\mathbf{P a}$ & arterial partial pressure \\
\hline PAH & Pulmonary artery hypertension \\
\hline PB & periodic breathing \\
\hline $\mathrm{P}_{\mathrm{ET}} \mathrm{CO}_{2}$ & end-tidal partial pressure for carbon dioxide \\
\hline$\dot{\mathrm{v}} \mathrm{CO}_{2}$ & pulmonary carbon dioxide output \\
\hline VD & dead space \\
\hline$\dot{\mathrm{V}} \mathbf{E}$ & minute ventilation \\
\hline$\dot{\mathrm{V}} \mathrm{O}_{2}$ & pulmonary oxygen uptake \\
\hline $\mathbf{V}_{\mathbf{T}}$ & tidal volume \\
\hline
\end{tabular}

\section{References}

1. Ceridon M, Wanner A, Johnson BD. Does the bronchial circulation contribute to congestion in heart failure? Med Hypotheses. 2009;73(3):414-419. doi:10.1016/j.mehy.2009.03.033 [PubMed: 19464810]

2. Olson TP, Beck KC, Johnson JB, Johnson BD. Competition for Intrathoracic Space Reduces Lung Capacity in Patients With Chronic Heart Failure*A Radiographic Study. CHEST. 2006;130(1):164171. doi:10.1378/chest.130.1.164 [PubMed: 16840397]

3. Guazzi M Alveolar Gas Diffusion Abnormalities in Heart Failure. Journal of Cardiac Failure. 2008;14(8):695-702. doi:10.1016/j.cardfail.2008.06.004 [PubMed: 18926442]

4. Siegel JL, Miller A, Brown LK, DeLuca A, Teirstein AS. Pulmonary diffusing capacity in left ventricular dysfunction. Chest. 1990;98(3):550-553. [PubMed: 2118446]

5. Arena R, Myers J, Abella J, et al. The Partial Pressure of Resting End-Tidal Carbon Dioxide Predicts Major Cardiac Events In Patients with Systolic Heart Failure. Am Heart J. 2008;156(5): 982-988. doi:10.1016/j.ahj.2008.06.024 [PubMed: 19061716]

6. Woods PR, Olson TP, Frantz RP, Johnson BD. Causes of breathing inefficiency during exercise in heart failure. J Card Fail. 2010;16(10):835-842. doi:10.1016/j.cardfail.2010.05.003 [PubMed: 20932466]

7. Cundrle I, Somers VK, Johnson BD, Scott CG, Olson LJ. Exercise end-tidal CO2 predicts central sleep apnea in patients with heart failure. Chest. 2015;147(6):1566-1573. doi:10.1378/chest. 14-2114 [PubMed: 25742609]

8. Johnson BD, Beck KC, Olson LJ, et al. Ventilatory constraints during exercise in patients with chronic heart failure. Chest. 2000;117(2):321-332. [PubMed: 10669670]

9. Ceridon ML, Morris NR, Hulsebus ML, Olson TP, Lalande S, Johnson BD. Influence of bronchial blood flow and conductance on pulmonary function in stable systolic heart failure. Respir Physiol Neurobiol. 2011;177(3):256-264. doi:10.1016/j.resp.2011.04.020 [PubMed: 21545852]

10. Johnson BD, Beck KC, Olson LJ, et al. Pulmonary function in patients with reduced left ventricular function: influence of smoking and cardiac surgery. Chest. 2001;120(6):1869-1876. [PubMed: 11742915] 
11. Agostoni PG, Doria E, Bortone F, Antona C, Moruzzi P. Systemic to pulmonary bronchial blood flow in heart failure. Chest. 1995;107(5):1247-1252. [PubMed: 7750314]

12. Wagner EM, Mitzner WA. Effect of left atrial pressure on bronchial vascular hemodynamics. J Appl Physiol. 1990;69(3):837-842. doi:10.1152/jappl.1990.69.3.837 [PubMed: 2246171]

13. Agostoni P, Cattadori G, Bussotti M, Apostolo A. Cardiopulmonary interaction in heart failure. Pulm Pharmacol Ther. 2007;20(2):130-134. doi:10.1016/j.pupt.2006.03.001 [PubMed: 16702004]

14. Long WM, Yerger LD, Martinez H, et al. Modification of bronchial blood flow during allergic airway responses. Journal of Applied Physiology. 1988;65(1):272-282. doi:10.1152/jappl. 1988.65.1.272 [PubMed: 3136132]

15. Lorenzi-Filho G, Azevedo ER, Parker JD, Bradley TD. Relationship of carbon dioxide tension in arterial blood to pulmonary wedge pressure in heart failure. Eur Respir J. 2002;19(1):37-40. [PubMed: 11843325]

16. Ceridon ML, Snyder EM, Olson TP, Hulsebus ML, Johnson BD. Influence of acute graded hypoxia on the bronchial circulation in healthy humans. The FASEB Journal. 2008;22(1_supplement): 1150.15-1150.15. doi:10.1096/fasebj.22.1_supplement.1150.15

17. King LS, Nielsen S, Agre P, Brown RH. Decreased pulmonary vascular permeability in aquaporin-1-null humans. Proc Natl Acad Sci USA. 2002;99(2):1059-1063. doi:10.1073/pnas. 022626499 [PubMed: 11773634]

18. Ceridon ML, Snyder EM, Strom NA, Tschirren J, Johnson BD. Influence of rapid fluid loading on airway structure and function in healthy humans. J Card Fail. 2010;16(2):175-185. doi:10.1016/ j.cardfail.2009.08.005 [PubMed: 20142030]

19. Bucca CB, Brussino L, Battisti A, et al. Diuretics in obstructive sleep apnea with diastolic heart failure. Chest. 2007;132(2):440-446. doi:10.1378/chest.07-0311 [PubMed: 17699130]

20. Shin JT, Semigran MJ. Heart Failure and Pulmonary Hypertension. Heart Fail Clin. 2010;6(2): 215-222. doi:10.1016/j.hfc.2009.11.007 [PubMed: 20347789]

21. Meyer FJ, Ewert R, Hoeper MM, et al. Peripheral airway obstruction in primary pulmonary hypertension. Thorax. 2002;57(6):473-476. [PubMed: 12037220]

22. Rastogi D, Ngai P, Barst RJ, Koumbourlis AC. Lower airway obstruction, bronchial hyperresponsiveness, and primary pulmonary hypertension in children. Pediatr Pulmonol. 2004;37(1):50-55. doi:10.1002/ppul.10363 [PubMed: 14679489]

23. Rothman A, Kulik TJ. Pulmonary hypertension and asthma in two patients with congenital heart disease. Am J Dis Child. 1989;143(8):977-979. [PubMed: 2756975]

24. Miller WW, Park CD, Waldhausen JA. Bronchial compression from enlarged, hypertensive right pulmonary artery with corrected transposition of great arteries, dextrocardia, and ventricular septal defect. Diagnosis and surgical treatment. J Thorac Cardiovasc Surg. 1970;60(2):233-236. [PubMed: 5451066]

25. Haworth SG, Hall SM, Panja M, Patel M. Peripheral pulmonary vascular and airway abnormalities in adolescents with rheumatic mitral stenosis. Int J Cardiol. 1988;18(3):405-416. [PubMed: 3360524]

26. Leeds SE, Uhley HN, Teleszky LB. Direct cannulation and injection lymphangiography of the canine cardiac and pulmonary efferent mediastinal lymphatics in experimental congestive heart failure. Invest Radiol. 1981;16(3):193-200. [PubMed: 6266975]

27. Agostoni P, Cattadori G, Guazzi M, Palermo P, Bussotti M, Marenzi G. Cardiomegaly as a possible cause of lung dysfunction in patients with heart failure. American Heart Journal. 2000;140(5):A17-A21. doi:10.1067/mhj.2000.110282

28. McCormack DG. Increase in vital capacity after cardiac transplantation. Am J Med. 1991;90(5): 660-661.

29. Puri S, Baker BL, Dutka DP, Oakley CM, Hughes JM, Cleland JG. Reduced alveolar-capillary membrane diffusing capacity in chronic heart failure. Its pathophysiological relevance and relationship to exercise performance. Circulation. 1995;91(11):2769-2774. [PubMed: 7758183]

30. Robertson HT, Pellegrino R, Pini D, et al. Exercise response after rapid intravenous infusion of saline in healthy humans. J Appl Physiol. 2004;97(2):697-703. doi:10.1152/japplphysiol. 00108.2004 [PubMed: 15090479] 
31. Mutlu GM, Factor P. Alveolar epithelial beta2-adrenergic receptors. Am J Respir Cell Mol Biol. 2008;38(2):127-134. doi:10.1165/rcmb.2007-0198TR [PubMed: 17709598]

32. Guazzi M, Pontone G, Brambilla R, Agostoni P, Rèina G. Alveolar--capillary membrane gas conductance: a novel prognostic indicator in chronic heart failure. Eur Heart J. 2002;23(6):467476. doi:10.1053/euhj.2001.2803 [PubMed: 11863349]

33. Lalande S, Yerly P, Faoro V, Naeije R. Pulmonary vascular distensibility predicts aerobic capacity in healthy individuals. J Physiol (Lond). 2012;590(17):4279-4288. doi:10.1113/jphysiol. 2012.234310 [PubMed: 22733662]

34. Agostoni PG, Marenzi GC, Pepi M, et al. Isolated ultrafiltration in moderate congestive heart failure. J Am Coll Cardiol. 1993;21(2):424-431. [PubMed: 8426008]

35. Mettauer B, Lampert E, Charloux A, et al. Lung membrane diffusing capacity, heart failure, and heart transplantation. American Journal of Cardiology. 1999;83(1):62-67. doi:10.1016/ S0002-9149(98)00784-X [PubMed: 10073787]

36. Cundrle I, Johnson BD, Somers VK, Scott CG, Rea RF, Olson LJ. Effect of cardiac resynchronization therapy on pulmonary function in patients with heart failure. Am J Cardiol. 2013;112(6):838-842. doi:10.1016/j.amjcard.2013.05.012 [PubMed: 23747043]

37. Agostoni P, Swenson ER, Fumagalli R, et al. Acute high-altitude exposure reduces lung diffusion: data from the HIGHCARE Alps project. Respir Physiol Neurobiol. 2013;188(2):223-228. doi: 10.1016/j.resp.2013.04.005 [PubMed: 23619193]

38. Banfi C, Agostoni P. Surfactant protein B: From biochemistry to its potential role as diagnostic and prognostic marker in heart failure. International Journal of Cardiology. 2016;221:456-462. doi: 10.1016/j.ijcard.2016.07.003 [PubMed: 27414721]

39. De Pasquale CG, Arnolda LF, Doyle IR, Aylward PE, Chew DP, Bersten AD. Plasma surfactant protein-B: a novel biomarker in chronic heart failure. Circulation. 2004;110(9):1091-1096. doi: 10.1161/01.CIR.0000140260.73611.FA [PubMed: 15302797]

40. Gargiulo P, Banfi C, Ghilardi S, et al. Surfactant-Derived Proteins as Markers of Alveolar Membrane Damage in Heart Failure. PLOS ONE. 2014;9(12):e115030. doi:10.1371/journal.pone. 0115030 [PubMed: 25514679]

41. Magrì D, Banfi C, Maruotti A, et al. Plasma immature form of surfactant protein type B correlates with prognosis in patients with chronic heart failure. A pilot single-center prospective study. Int J Cardiol. 2015;201:394-399. doi:10.1016/j.ijcard.2015.08.105 [PubMed: 26310985]

42. Fanfulla F, Mortara A, Maestri R, et al. The development of hyperventilation in patients with chronic heart failure and Cheyne-Strokes respiration: a possible role of chronic hypoxia. Chest. 1998;114(4):1083-1090. [PubMed: 9792581]

43. Arena R, Myers J, Aslam SS, Varughese EB, Peberdy MA. Peak VO2 and VE/VCO2 slope in patients with heart failure: a prognostic comparison. Am Heart J. 2004;147(2):354-360. doi: 10.1016/j.ahj.2003.07.014 [PubMed: 14760336]

44. Johnson RL. Gas Exchange Efficiency in Congestive Heart Failure. Circulation. 2000;101(24): 2774-2776. doi:10.1161/01.CIR.101.24.2774 [PubMed: 10859280]

45. Roberts AM, Bhattacharya J, Schultz HD, Coleridge HM, Coleridge JC. Stimulation of pulmonary vagal afferent C-fibers by lung edema in dogs. Circ Res. 1986;58(4):512-522. [PubMed: 3698217]

46. Lloyd TCJ. Effect of increased left atrial pressure on breathing frequency in anesthetized dog. J Appl Physiol. 1990;69(6):1973-1980. [PubMed: 2076990]

47. Olson TP, Frantz RP, Snyder EM, O’Malley KA, Beck KC, Johnson BD. Effects of acute changes in pulmonary wedge pressure on periodic breathing at rest in heart failure patients. Am Heart J. 2007;153(1):104.e1-7. doi:10.1016/j.ahj.2006.10.003 [PubMed: 17174646]

48. Olson TP, Joyner MJ, Johnson BD. Influence of locomotor muscle metaboreceptor stimulation on the ventilatory response to exercise in heart failure. Circ Heart Fail. 2010;3(2):212-219. doi: 10.1161/CIRCHEARTFAILURE.109.879684 [PubMed: 20061520]

49. Olson LJ, Arruda-Olson AM, Somers VK, Scott CG, Johnson BD. Exercise Oscillatory Ventilation. Chest. 2008;133(2):474-481. doi:10.1378/chest.07-2146 [PubMed: 18071013]

50. Massie BM, Simonini A, Sahgal P, Wells L, Dudley GA. Relation of systemic and local muscle exercise capacity to skeletal muscle characteristics in men with congestive heart failure. Journal of 
the American College of Cardiology. 1996;27(1):140-145. doi:10.1016/0735-1097(95)00416-5 [PubMed: 8522687]

51. Wilson JR, Mancini DM. Factors contributing to the exercise limitation of heart failure. J Am Coll Cardiol. 1993;22(4 Suppl A):93A-98A. [PubMed: 8509570]

52. Wensel R, Francis DP, Georgiadou P, et al. Exercise hyperventilation in chronic heart failure is not caused by systemic lactic acidosis. Eur J Heart Fail. 2005;7(7):1105-1111. doi:10.1016/j.ejheart. 2004.12.005 [PubMed: 16326362]

53. Wasserman K, Zhang YY, Gitt A, et al. Lung function and exercise gas exchange in chronic heart failure. Circulation. 1997;96(7):2221-2227. [PubMed: 9337193]

54. Banning AP, Lewis NP, Northridge DB, Elborn JS, Hendersen AH. Perfusion/ventilation mismatch during exercise in chronic heart failure: an investigation of circulatory determinants. Br Heart J. 1995;74(1):27-33. [PubMed: 7662449]

55. Reindl I, Wernecke K-D, Opitz C, et al. Impaired ventilatory efficiency in chronic heart failure: Possible role of pulmonary vasoconstriction. American Heart Journal. 1998;136(5):778-785. doi: 10.1016/S0002-8703(98)70121-8 [PubMed: 9812071]

56. Francis DP, Shamim W, Davies LC, et al. Cardiopulmonary exercise testing for prognosis in chronic heart failure: continuous and independent prognostic value from VE/VCO2slope and peak VO2. Eur Heart J. 2000;21(2):154-161. doi:10.1053/euhj.1999.1863 [PubMed: 10637089]

57. Arena R, Humphrey R. Comparison of ventilatory expired gas parameters used to predict hospitalization in patients with heart failure. American Heart Journal. 2002;143(3):427-432. doi: 10.1067/mhj.2002.119607 [PubMed: 11868047]

58. Corrà U, Mezzani A, Bosimini E, Scapellato F, Imparato A, Giannuzzi P. Ventilatory response to exercise improves risk stratification in patients with chronic heart failure and intermediate functional capacity. American Heart Journal. 2002;143(3):418-426. doi:10.1067/mhj.2002.120772 [PubMed: 11868046]

59. Chua TP, Ponikowski P, Harrington D, et al. Clinical correlates and prognostic significance of the ventilatory response to exercise in chronic heart failure. J Am Coll Cardiol. 1997;29(7):15851590. [PubMed: 9180123]

60. Kleber FX, Vietzke G, Wernecke KD, et al. Impairment of Ventilatory Efficiency in Heart Failure Prognostic Impact. Circulation. 2000;101(24):2803-2809. doi:10.1161/01.CIR.101.24.2803 [PubMed: 10859285]

61. Myers J, Gujja P, Neelagaru S, et al. End-tidal CO2 pressure and cardiac performance during exercise in heart failure. Med Sci Sports Exerc. 2009;41(1):19-25. doi:10.1249/MSS. 0b013e318184c945 [PubMed: 19092707]

62. Arena R, Peberdy MA, Myers J, Guazzi M, Tevald M. Prognostic value of resting end-tidal carbon dioxide in patients with heart failure. Int J Cardiol. 2006;109(3):351-358. doi:10.1016/j.ijcard. 2005.06.032 [PubMed: 16046017]

63. Seguchi O, Hisamatsu E, Nakano A, et al. Low partial pressure of end-tidal carbon dioxide predicts left ventricular assist device implantation in patients with advanced chronic heart failure. Int J Cardiol. 2017;230:40-46. doi:10.1016/j.ijcard.2016.12.102 [PubMed: 28038817]

64. Ingle L, Rigby AS, Sloan R, et al. Development of a composite model derived from cardiopulmonary exercise tests to predict mortality risk in patients with mild-to-moderate heart failure. Heart. 2014;100(10):781-786. doi:10.1136/heartjnl-2013-304614 [PubMed: 24567314]

65. Myers J, Arena R, Dewey F, et al. A cardiopulmonary exercise testing score for predicting outcomes in patients with heart failure. Am Heart J. 2008;156(6):1177-1183. doi:10.1016/j.ahj. 2008.07.010 [PubMed: 19033016]

66. Cundrle I, Johnson BD, Rea RF, Scott CG, Somers VK, Olson LJ. Modulation of ventilatory reflex control by cardiac resynchronization therapy. J Card Fail. 2015;21(5):367-373. doi:10.1016/ j.cardfail.2014.12.013 [PubMed: 25576681]

67. Bradley TD. The ups and downs of periodic breathingImplications for mortality in heart failure*. J Am Coll Cardiol. 2003;41(12):2182-2184. doi:10.1016/S0735-1097(03)00470-4 [PubMed: 12821244] 
68. Leung RST, Douglas Bradley T. Sleep Apnea and Cardiovascular Disease. American Journal of Respiratory and Critical Care Medicine. 2001;164(12):2147-2165. doi:10.1164/ajrccm. 164.12.2107045 [PubMed: 11751180]

69. Francis DP, Willson K, Davies LC, Coats AJS, Piepoli M. Quantitative General Theory for Periodic Breathing in Chronic Heart Failure and Its Clinical Implications. Circulation. 2000;102(18):2214-2221. doi:10.1161/01.CIR.102.18.2214 [PubMed: 11056095]

70. Bradley TD, Phillipson EA. Central sleep apnea. Clin Chest Med. 1992;13(3):493-505. [PubMed: 1521415]

71. Clark AL, Piepoli M, Coats AJ. Skeletal muscle and the control of ventilation on exercise: evidence for metabolic receptors. Eur J Clin Invest. 1995;25(5):299-305. [PubMed: 7628515]

72. Khoo MC, Kronauer RE, Strohl KP, Slutsky AS. Factors inducing periodic breathing in humans: a general model. J Appl Physiol. 1982;53(3):644-659. [PubMed: 7129986]

73. Leite JJ, Mansur AJ, de Freitas HFG, et al. Periodic breathing during incremental exercise predicts mortality in patients with chronic heart failure evaluated for cardiac transplantation. J Am Coll Cardiol. 2003;41(12):2175-2181. [PubMed: 12821243]

74. Steens RD, Millar TW, Su X, et al. Effect of inhaled 3\% CO2 on Cheyne-Stokes respiration in congestive heart failure. Sleep. 1994;17(1):61-68. [PubMed: 8191204]

75. Murphy RM, Shah RV, Malhotra R, et al. Exercise oscillatory ventilation in systolic heart failure: an indicator of impaired hemodynamic response to exercise. Circulation. 2011;124(13):14421451. doi:10.1161/CIRCULATIONAHA.111.024141 [PubMed: 21875912]

76. Agostoni P, Apostolo A, Albert RK. Mechanisms of periodic breathing during exercise in patients with chronic heart failure. Chest. 2008;133(1):197-203. doi:10.1378/chest.07-1439 [PubMed: 18187746]

77. Balady Gary J, Arena Ross, Sietsema Kathy, et al. Clinician's Guide to Cardiopulmonary Exercise Testing in Adults. Circulation. 2010;122(2):191-225. doi:10.1161/CIR.0b013e3181e52e69 [PubMed: 20585013]

78. Olson TP, Snyder EM, Johnson BD. Exercise-disordered breathing in chronic heart failure. Exerc Sport Sci Rev. 2006;34(4):194-201. doi:10.1249/01.jes.0000240022.30373.a2 [PubMed: 17031258]

79. Guazzi M, Myers J, Peberdy MA, Bensimhon D, Chase P, Arena R. Exercise oscillatory breathing in diastolic heart failure: prevalence and prognostic insights. Eur Heart J. 2008;29(22):2751-2759. doi:10.1093/eurheartj/ehn437 [PubMed: 18836201]

80. Ponikowski P, Anker SD, Chua TP, et al. Oscillatory breathing patterns during wakefulness in patients with chronic heart failure: clinical implications and role of augmented peripheral chemosensitivity. Circulation. 1999;100(24):2418-2424. [PubMed: 10595954]

81. Sun X-G, Hansen JE, Beshai JF, Wasserman K. Oscillatory breathing and exercise gas exchange abnormalities prognosticate early mortality and morbidity in heart failure. J Am Coll Cardiol. 2010;55(17):1814-1823. doi:10.1016/j.jacc.2009.10.075 [PubMed: 20413031]

82. Guazzi M, Arena R, Pellegrino M, et al. Prevalence and characterization of exercise oscillatory ventilation in apparently healthy individuals at variable risk for cardiovascular disease: A subanalysis of the EURO-EX trial. Eur J Prev Cardiol. 2016;23(3):328-334. doi: 10.1177/2047487315580445 [PubMed: 25868603]

83. Corrà U, Pistono M, Mezzani A, et al. Sleep and Exertional Periodic Breathing in Chronic Heart Failure. Circulation. 2006;113(1):44-50. doi:10.1161/CIRCULATIONAHA.105.543173 [PubMed: 16380551]

84. Roche F, Maudoux D, Jamon Y, Barthelemy J-C. Monitoring of ventilation during the early part of cardiopulmonary exercise testing: the first step to detect central sleep apnoea in chronic heart failure. Sleep Med. 2008;9(4):411-417. doi:10.1016/j.sleep.2007.06.012 [PubMed: 17761455]

85. Wolk R, Kara T, Somers VK. Sleep-Disordered Breathing and Cardiovascular Disease. Circulation. 2003;108(1):9-12. doi:10.1161/01.CIR.0000072346.56728.E4 [PubMed: 12847053]

86. Bradley TD, Floras JS. Sleep Apnea and Heart Failure Part II: Central Sleep Apnea. Circulation. 2003;107(13):1822-1826. doi:10.1161/01.CIR.0000061758.05044.64 [PubMed: 12682029] 
87. Caples SM, Wolk R, Somers VK. Influence of cardiac function and failure on sleep-disordered breathing: evidence for a causative role. J Appl Physiol. 2005;99(6):2433-2439. doi:10.1152/ japplphysiol.00676.2005 [PubMed: 16288101]

88. Eckert DJ, Jordan AS, Merchia P, Malhotra A. Central sleep apnea: Pathophysiology and treatment. Chest. 2007;131(2):595-607. doi:10.1378/chest.06.2287 [PubMed: 17296668]

89. Olson LJ, Somers VK. Sleep apnea: implications for heart failure. Curr Heart Fail Rep. 2007;4(2): 63-69. [PubMed: 17521497]

90. Javaheri S Heart failure and sleep apnea: emphasis on practical therapeutic options. Clinics in chest medicine. 24(2):207-222. [PubMed: 12800779]

91. Mansfield D, Kaye DM, Brunner La Rocca H, Solin P, Esler MD, Naughton MT. Raised sympathetic nerve activity in heart failure and central sleep apnea is due to heart failure severity. Circulation. 2003;107(10):1396-1400. [PubMed: 12642360]

92. Naughton MT, Benard DC, Liu PP, Rutherford R, Rankin F, Bradley TD. Effects of nasal CPAP on sympathetic activity in patients with heart failure and central sleep apnea. American Journal of Respiratory and Critical Care Medicine. 1995;152(2):473-479. doi:10.1164/ajrccm.152.2.7633695 [PubMed: 7633695]

93. Khayat R, Abraham W, Patt B, et al. Central sleep apnea is a predictor of cardiac readmission in hospitalized patients with systolic heart failure. J Card Fail. 2012;18(7):534-540. doi:10.1016/ j.cardfail.2012.05.003 [PubMed: 22748486]

94. Naughton MT, Bradley TD. Sleep apnea in congestive heart failure. Clin Chest Med. 1998;19(1): 99-113. [PubMed: 9554221]

95. Owan TE, Hodge DO, Herges RM, Jacobsen SJ, Roger VL, Redfield MM. Trends in prevalence and outcome of heart failure with preserved ejection fraction. N Engl J Med. 2006;355(3):251259. doi:10.1056/NEJMoa052256 [PubMed: 16855265]

96. Burkhoff D Mortality in heart failure with preserved ejection fraction: an unacceptably high rate. Eur Heart J. 2012;33(14):1718-1720. doi:10.1093/eurheartj/ehr339 [PubMed: 21900293]

97. Smith GL, Masoudi FA, Vaccarino V, Radford MJ, Krumholz HM. Outcomes in heart failure patients with preserved ejection fraction: mortality, readmission, and functional decline. J Am Coll Cardiol. 2003;41(9):1510-1518. [PubMed: 12742291]

98. Guazzi M, Myers J, Arena R. Cardiopulmonary exercise testing in the clinical and prognostic assessment of diastolic heart failure. J Am Coll Cardiol. 2005;46(10):1883-1890. doi:10.1016/ j.jacc.2005.07.051 [PubMed: 16286176]

99. Yan J, Gong S-J, Li L, et al. Combination of B-type natriuretic peptide and minute ventilation/ carbon dioxide production slope improves risk stratification in patients with diastolic heart failure. Int J Cardiol. 2013;162(3):193-198. doi:10.1016/j.ijcard.2011.07.017 [PubMed: 21807423]

100. Shafiq A, Brawner CA, Aldred HA, et al. Prognostic value of cardiopulmonary exercise testing in heart failure with preserved ejection fraction. The Henry Ford HospITal CardioPulmonary EXercise Testing (FIT-CPX) project. Am Heart J. 2016;174:167-172. doi:10.1016/j.ahj. 2015.12.020 [PubMed: 26995385]

101. Nadruz W, West E, Sengeløv M, et al. Prognostic Value of Cardiopulmonary Exercise Testing in Heart Failure With Reduced, Midrange, and Preserved Ejection Fraction. J Am Heart Assoc. 2017;6(11). doi:10.1161/JAHA.117.006000

102. Butler J, Chomsky DB, Wilson JR. Pulmonary hypertension and exercise intolerance in patients with heart failure. J Am Coll Cardiol. 1999;34(6):1802-1806. [PubMed: 10577573]

103. Lam CSP, Roger VL, Rodeheffer RJ, Borlaug BA, Enders FT, Redfield MM. Pulmonary hypertension in heart failure with preserved ejection fraction: a community-based study. J Am Coll Cardiol. 2009;53(13):1119-1126. doi:10.1016/j.jacc.2008.11.051 [PubMed: 19324256]

104. Rausch CM, Taylor AL, Ross H, Sillau S, Ivy DD. Ventilatory efficiency slope correlates with functional capacity, outcomes, and disease severity in pediatric patients with pulmonary hypertension,., Int J Cardiol. 2013;169(6):445-448. doi:10.1016/j.ijcard.2013.10.012 [PubMed: 24144928]

105. Faisal A, Webb KA, Guenette JA, et al. Effect of age-related ventilatory inefficiency on respiratory sensation during exercise. Respir Physiol Neurobiol. 2015;205:129-139. doi:10.1016/ j.resp.2014.10.017 [PubMed: 25447683] 
106. Matsumoto A, Itoh $\mathrm{H}$, Eto $\mathrm{Y}$, et al. End-tidal $\mathrm{CO} 2$ pressure decreases during exercise in cardiac patients: association with severity of heart failure and cardiac output reserve. J Am Coll Cardiol. 2000;36(1):242-249. [PubMed: 10898441]

107. Sun XG, Hansen JE, Oudiz RJ, Wasserman K. Exercise pathophysiology in patients with primary pulmonary hypertension. Circulation. 2001;104(4):429-435. [PubMed: 11468205]

108. O'Donnell DE, Elbehairy AF, Berton DC, Domnik NJ, Neder JA. Advances in the Evaluation of Respiratory Pathophysiology during Exercise in Chronic Lung Diseases. Front Physiol. 2017;8. doi:10.3389/fphys.2017.00082 [PubMed: 28167916]

109. Aguggini G, Clement MG, Widdicombe JG. Lung reflexes affecting the larynx in the pig, and the effect of pulmonary microembolism. Q J Exp Physiol. 1987;72(1):95-104. [PubMed: 3562780] 


\section{Synopsis:}

The heart and lungs are intimately linked. Hence, impaired function of one organ may lead to changes in the other. Accordingly, heart failure is associated with airway obstruction, loss of lung volume, impaired gas exchange and abnormal ventilatory control. Cardiopulmonary exercise testing is an excellent tool for evaluation of gas exchange and ventilatory control. Indeed, many parameters routinely measured during cardiopulmonary exercise testing including the level of minute ventilation per unit of carbon dioxide production $\left(\mathrm{V}_{\mathrm{E}} / \mathrm{VCO}_{2}\right.$ slope $)$ and the presence of exercise oscillatory ventilation have been found to be strongly associated with prognosis in HF patients. 


\section{Key points:}

1. Heart failure is associated with airway obstruction, reduced lung volume, impaired gas exchange and abnormal ventilatory control.

2. Abnormal ventilatory control in heart failure patients manifests as hyperventilation at rest, during exercise and even with sleep.

3. Cardiopulmonary exercise testing detects abnormalities of gas exchange and ventilatory control.

4. Selected cardiopulmonary exercise testing parameters including $\mathrm{V}_{\mathrm{E}} / \mathrm{VCO}_{2}$ slope and oscillatory breathing have been strongly associated with prognosis of heart failure patients. 
Airflow limitation (due to airway compression by pulmonary edema and/or mucosal edema secondary to bronchial congestion) and lung restriction (linked to cardiomegaly and increased lung elastic recoil) are common consequences of chronic heart failure. 
The efficiency of intra-pulmonary gas exchange can be decreased in heart failure due to a highly variable combination of interstitial edema, alveolar-capillary membrane remodeling and ventilation-perfusion mismatch. These abnormalities can be appreciated by the degree of impairment in hemoglobin-corrected $\mathrm{D}_{\mathrm{L}} \mathrm{CO}$. 
A high $\mathrm{V}_{\mathrm{E}} / \mathrm{VCO}_{2}$ in heart failure reflects an excessive ventilation for the prevailing metabolic demand due to alveolar hyperventilation secondary to increased stimulation or sensitivity of pulmonary receptors, increased sympathetic nerve activity and chemoreceptor overactivation and/or high "wasted" ventilation as a consequence of ventilationperfusion mismatch and a rapid and shallow breathing pattern. 
Abnormalities in the ventilatory control system are commonly found in advanced chronic heart failure: these derangements are exacerbated in physiological situations in which afferent stimulation is strongly influenced by metabolism e.g., exercise and sleep. 


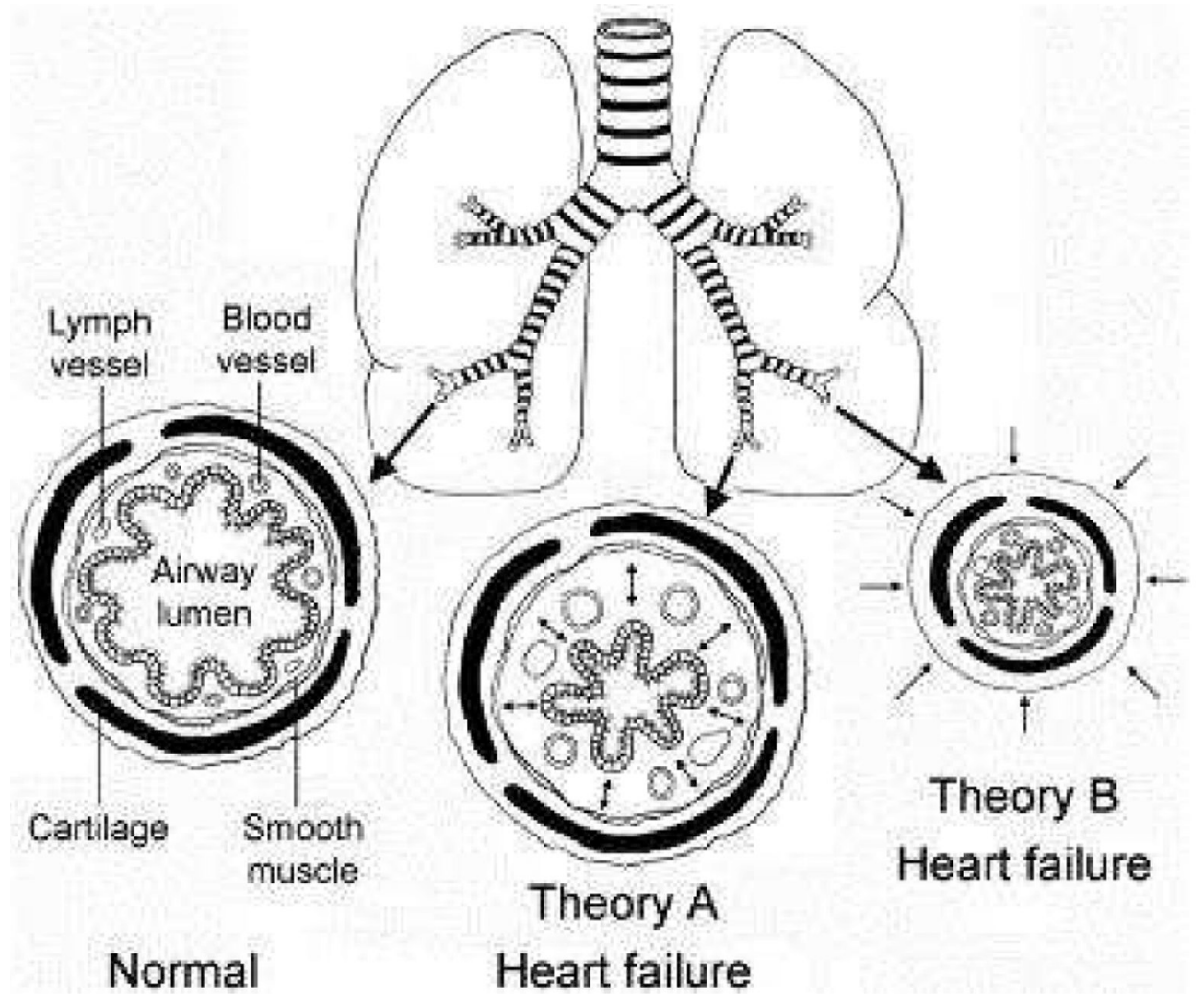

Figure 1.

Bronchial flow limitation in heart failure may be caused by mucosal edema due to bronchial congestion which may develop from either an increase in blood flow or an increase in blood volume (Theory A) or by bronchial compression which may be caused by reduction of intrathoracic space by either increase in heart size or by pulmonary edema (Theory B) (reprinted with permission from reference \#1, figure \#2, Ceridon et al 2009). 


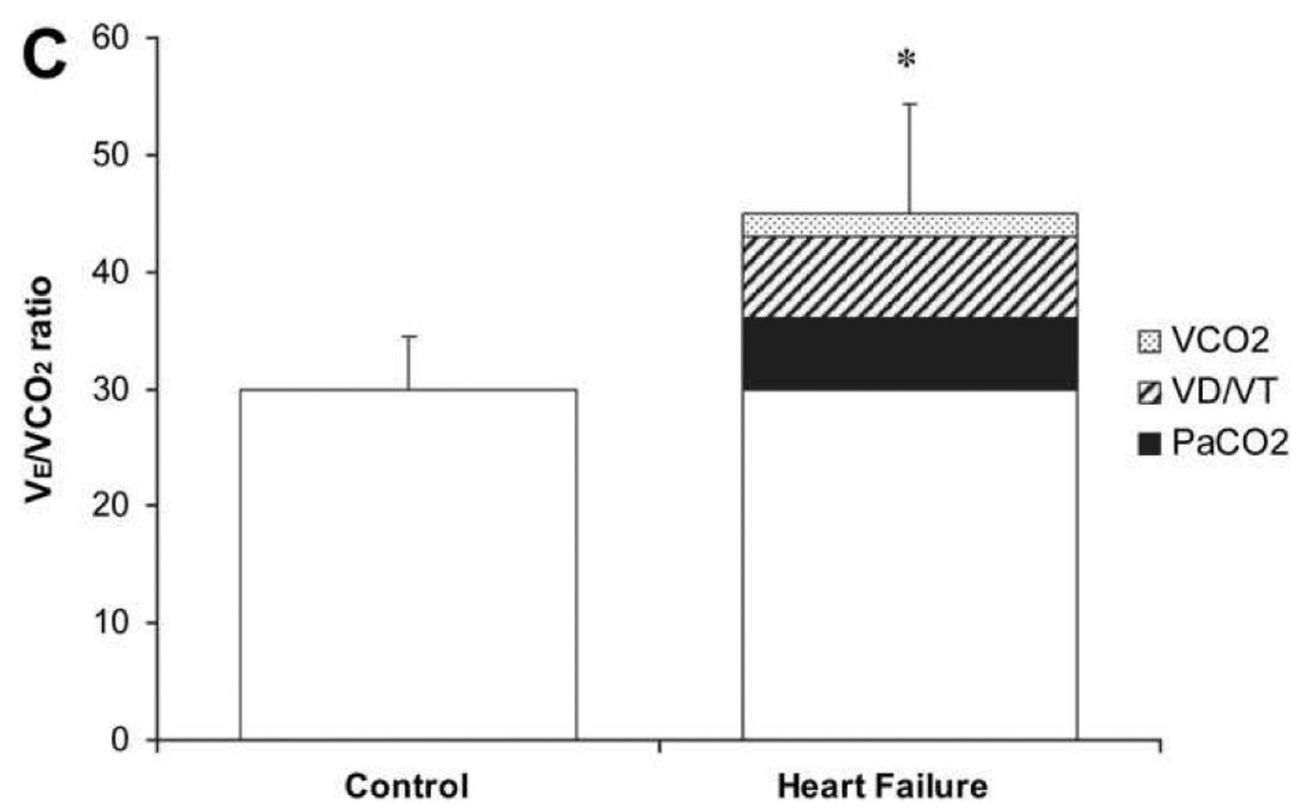

Figure 2.

In heart failure, both the increased ventilatory drive (low partial pressure of carbon dioxide $\left(\mathrm{PaCO}_{2}\right)$ ) and ventilation/perfusion mismatch (high dead space volume to tidal volume ratio $\left(\mathrm{V}_{\mathrm{D}} / \mathrm{V}_{\mathrm{T}}\right)$ ) contribute nearly equally to the increase in ventilatory inefficiency (higher $\mathrm{V}_{\mathrm{E}} / \mathrm{VCO}_{2}$ ) (reprinted with permission from reference \#6, figure \#3C, Woods et al, 2010). 


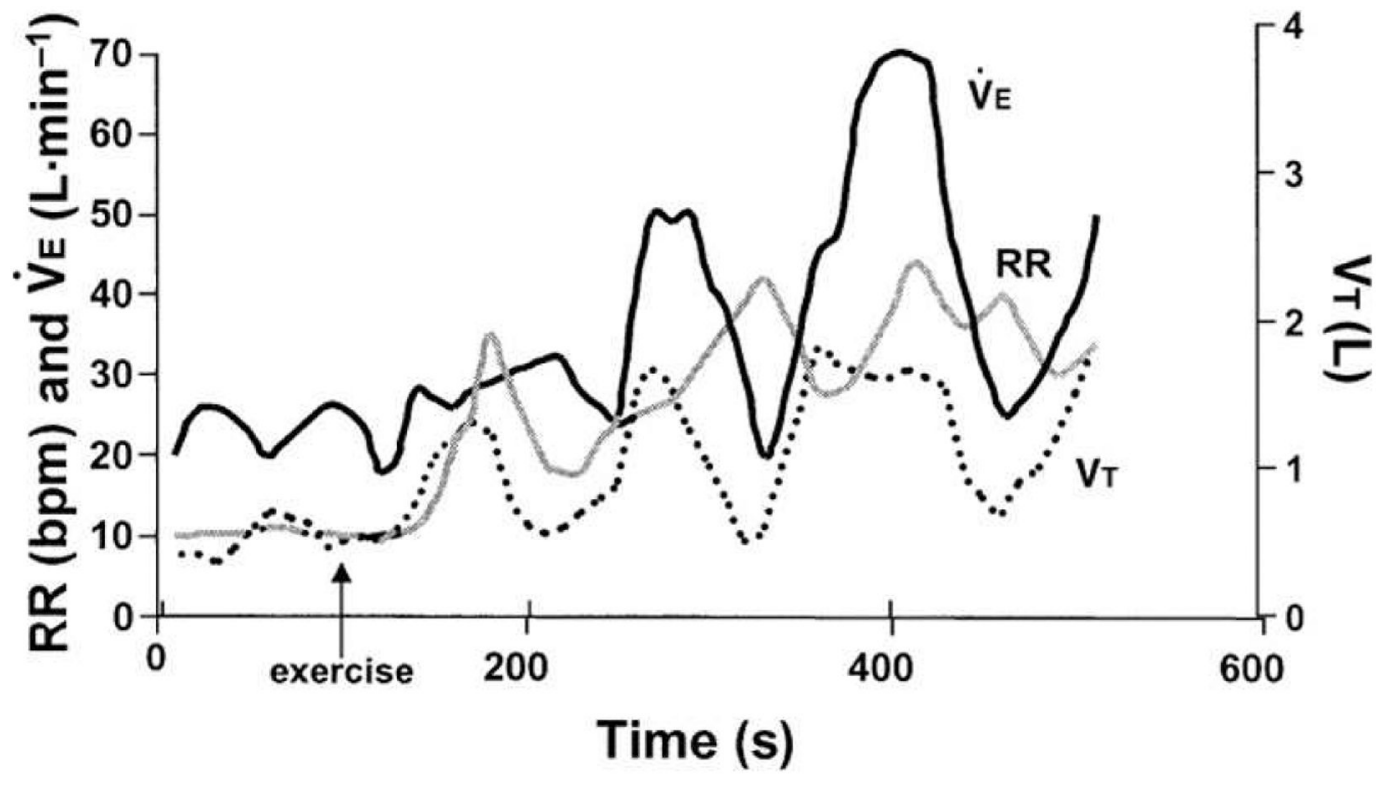

Figure 3.

Exercise oscillatory ventilation is a consequence of respiratory control system instability characterized by waxing and waning of tidal volume $\left(\mathrm{V}_{\mathrm{T}}\right)$, breathing frequency $(\mathrm{RR})$ and minute ventilation $\left(\mathrm{V}_{\mathrm{E}}\right)$ without interposed apnea due to oscillations of central respiratory drive. (Reprinted with permission from reference \#78, figure \#10, Olson et al 2006) 